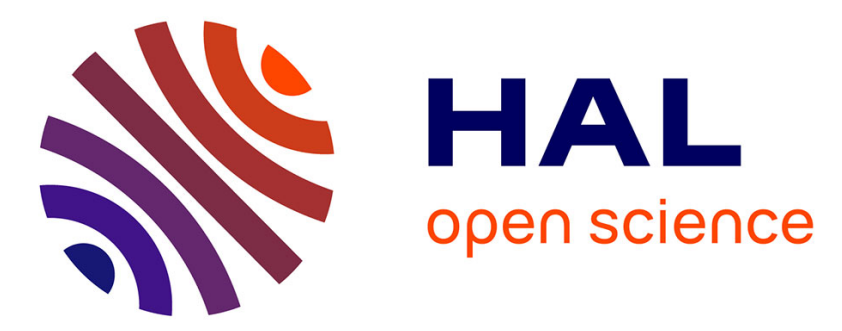

\title{
Positive effects of elevated CO2 and its interaction with nitrogen on safflower physiology and growth
}

\author{
Shiren Mohamed, Anita Jellings, Michael Fuller
}

\section{To cite this version:}

Shiren Mohamed, Anita Jellings, Michael Fuller. Positive effects of elevated CO2 and its interaction with nitrogen on safflower physiology and growth. Agronomy for Sustainable Development, 2013, 33 (3), pp.497-505. 10.1007/s13593-013-0137-x . hal-01201388

\section{HAL Id: hal-01201388 \\ https://hal.science/hal-01201388}

Submitted on 17 Sep 2015

HAL is a multi-disciplinary open access archive for the deposit and dissemination of scientific research documents, whether they are published or not. The documents may come from teaching and research institutions in France or abroad, or from public or private research centers.
L'archive ouverte pluridisciplinaire HAL, est destinée au dépôt et à la diffusion de documents scientifiques de niveau recherche, publiés ou non, émanant des établissements d'enseignement et de recherche français ou étrangers, des laboratoires publics ou privés. 


\title{
Positive effects of elevated $\mathrm{CO}_{2}$ and its interaction with nitrogen on safflower physiology and growth
}

\author{
Shiren J. Mohamed • Anita J. Jellings • Michael P. Fuller
}

Accepted: 11 February 2013 /Published online: 15 March 2013

(C) INRA and Springer-Verlag France 2013

\begin{abstract}
Over the last two decades, the impact of elevated $\mathrm{CO}_{2}$ on crops has become a major issue in the context of climate change. Increasing $\mathrm{CO}_{2}$ levels should modify the plant demand for nutrients, but precise effects on plant physiology are poorly known. Here, we studied the effect of ambient $\mathrm{CO}_{2}$ at $400 \mu \mathrm{mol} \mathrm{mol}{ }^{-1}$ and high $\mathrm{CO}_{2}$ at $1,000 \mu \mathrm{mol} \mathrm{mol}{ }^{-1}$ on safflower (Carthamus tinctorius L.) at $\mathrm{N}$ levels from 25 to $175 \mathrm{~kg} \mathrm{ha}^{-1}$. Growth and physiology of safflower were assessed in pots in controlled enclosure chambers in a glasshouse. Overall results show that high $\mathrm{CO}_{2}$ increased assimilation rate by $+27 \%$, leaf area index (LAI) by $+28 \%$, total above-ground dry weight by $+51 \%$, and total above-ground dry weight by $+43 \%$ at harvest. High $\mathrm{CO}_{2}$ reduced stomatal conductance by $-29 \%$ and transpiration rate by $-18 \%$. At anthesis, results show that high $\mathrm{CO}_{2}$ increases assimilation rate by $+13 \%$, LAI by $+2 \%$, and above-ground dry weight by $+34 \%$. At anthesis, results also show that high $\mathrm{CO}_{2}$ decreases leaf $\mathrm{N}$ and chlorophyll content.
\end{abstract}

Keywords Elevated $\mathrm{CO}_{2} \cdot$ Safflower $\cdot$ Gas exchange $\cdot$

Assimilation rate $\cdot \mathrm{LAI} \cdot$ Biomass

\section{Introduction}

Plant growth and productivity are affected by climate primarily due to changes in photosynthetic rate (Reddy et al.

S. J. Mohamed · A. J. Jellings $\cdot$ M. P. Fuller $(\bowtie)$

School of Biological and Biomedical Sciences, Plymouth University, Plymouth PL4 8AA, UK e-mail: mfuller@plymouth.ac.uk

S. J. Mohamed

Field Crops Department, College of Agriculture,

University of Sulaimani, Sulaimani, Kurdistan, Iraq
2010). It is frequently reported (Ainsworth and Long 2005; Ainsworth and Rogers 2007) that the rate of photosynthesis of $\mathrm{C}_{3}$ plants grown at elevated $\mathrm{CO}_{2}$ activates the carboxylation binding site of Rubisco, decreases the oxidation activity and hence inhibits photorespiration (Taiz and Fizeiger 2002). In addition, the higher $\mathrm{CO}_{2}$ reduces the stomatal conductance (Ainsworth and Rogers 2007) leading to enhanced water use efficiency (WUE) (Hsiao et al. 1999). As a result, enhancement of plant growth is expected, but the magnitude of the response differs between different crops (Ainsworth and Long 2005). Productivity is also strongly related to vegetative growth in terms of leaf area index (LAI) and directly associated with biomass since LAI determines the amount of light intercepted and ultimately the net photosynthetic rate (Gastal and Lemaire 2002). LAI is widely reported to be increased at elevated $\mathrm{CO}_{2}$ (Campbell et al. 2001; Manderscheid et al. 2003).

In general, increased growth at elevated $\mathrm{CO}_{2}$ has been reported to increase demand for mineral nutrients (Reddy et al. 2004), and under low nitrogen supply, a reduction in photosynthetic capacity has often been suggested (Del Pozo et al. 2007; Drake et al. 1997). Primarily, because the enzymes of the Calvin cycle and thylakoids equate to the majority of the plant's protein content (Taiz and Fizeiger 2002) indirectly, nitrogen deficiency leads to a limit of sink development to utilize additional photoassimilate from the enhanced photosynthesis (Ainsworth et al. 2003). However, elevated $\mathrm{CO}_{2}$ can also increase photosynthetic nitrogen use efficiency (NUE) (Zerihun et al. 2000), and as a result, the negative effect of nitrogen deficiency may be ameliorated by elevated $\mathrm{CO}_{2}$ (Radoglou et al. 1992), and plant growth and biomass are sometimes not significantly different between low and high-nitrogen treatments at elevated $\mathrm{CO}_{2}$ (Larigauderie et al. 1988). To date, there are no reports in the literature concerning the effect of elevated $\mathrm{CO}_{2}$ on safflower physiology and growth in spite of the medical, 
pharmaceutical and economic importance that have been demonstrated for safflower (Dajue and Mundle 1996). Safflower is typically grown in the arid or semi-arid regions of the world (Johnston et al. 2002), many of which are facing potentially favourable climate change (Shaw et al. 2005), but many of these ecosystems are currently facing net loss of nutrient due to exploitative non-sustainable land use (Evans and Belnap 1999). It is important to evaluate the response of semi-arid crop species so that sustainable agronomic management plans can be developed to cope with future climate change scenarios.

The results reported here are the initial investigations of the effect of $\mathrm{CO}_{2}$ enrichment on physiology and growth of this crop grown in enclosed chambers using a perlite-based hydroponic system.

\section{Materials and methods}

Two experiments were carried out during the years 2011 and 2012 at Plymouth University, UK, and each experiment lasted approximately 6 months. Seeds of "Richters" Lemon Yellow (Richter Seeds Ltd, UK) were pre-germinated in an incubator for 3 days using a fluctuating 12-h/12-h temperature of 12 and $20-24{ }^{\circ} \mathrm{C}$. These pre-germinated seeds were sown in pots constructed from a cylindrical polypropylene pipe $30 \mathrm{~cm}$ high $\times 10 \mathrm{~cm}$ in diameter filled with standard grand perlite (William Sinclair Horticulture Ltd, UK). The base of each pot was a loosely fitting transparent graduated $500-\mathrm{mL}$ plastic beaker so that the level of the drainage fluid could be monitored after watering. Pots were placed in eight tightly sealed ventilated chambers $(60 \times 60 \times 140 \mathrm{~cm})$ located in a semi-controlled glasshouse with 16 pots per chamber (Fig. 1). Four chambers were supplied with elevated $\mathrm{CO}_{2}$ (approx. 1,000 $\mathrm{mmol} \mathrm{mol}^{-1}$ ) and four with ambient air $\left(400 \mu \mathrm{mol} \mathrm{mol}^{-1}\right)$. The experimental design was a randomized block with four replicates, with two ambient and two elevated chambers at each side of the

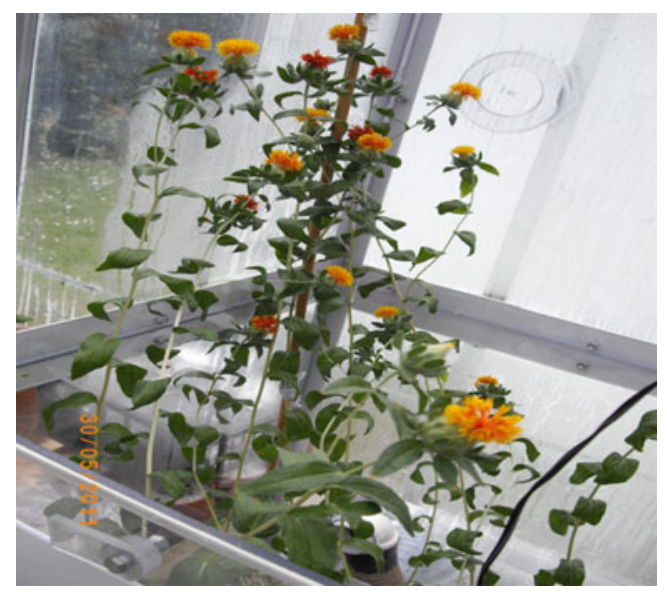

Fig. 1 Safflower plants growing in an enclosed elevated $\mathrm{CO}_{2}$ chamber glasshouse, and treatments were randomly assigned to the chambers. Pots were watered with $10-30 \mathrm{~mL}$ of a standard hydroponics growth solution (VitaLink Max Grow (soft water) $A$ and $B$ ) every 3-5 days until the plants reached the beginning of stem elongation (plants completely established). Thereafter, the amount of solution was increased to $50-200 \mathrm{~mL}$ and supplied every week to leave drainage fluid in the drainage beaker up to the $200-\mathrm{mL}$ graduation. Water was applied thereafter according to demand.

In the second experiment, the study layout was a split-plot design with $\mathrm{CO}_{2}$ as the main plot and nitrogen as sub-plots. Four chambers were supplied with elevated $\mathrm{CO}_{2}$ and four with ambient air, and nitrogen fertiliser equivalent to $25,70,125$ and $175 \mathrm{~kg} \mathrm{~N} \mathrm{ha}^{-1}$. Each chamber contained 16 pots (four pots per level of nitrogen). Pots were watered with $10-30 \mathrm{~mL}$ of standard hydroponics growth solution A and B every 3-5 days for 1 month. Thereafter, plants were irrigated with $50-200 \mathrm{~mL}$ complete Hoagland's solution minus nitrogen (for the recipe, see Hershey 1995) every 5-7 days. Different nitrogen rates were achieved by supplementing the Hoagland's at watering time. Four levels of nitrogen solution were prepared by dissolving $0.7,1.9,3.14$ and $4.22 \mathrm{~g}$ ammonium nitrate in $6.4 \mathrm{~L}$ of Hoagland solution to give the equivalent of $25,75,125$ and $175 \mathrm{~kg} \mathrm{~N} \mathrm{ha}^{-1}$ split into four doses at monthly intervals using $200 \mathrm{~mL}$ of Hoagland's solution per pot. Between fertigations, appropriate amounts of water were applied according to the demand as in expt 1.

Carbon dioxide was supplied using cylinders of compressed bottled $\mathrm{CO}_{2}$ (BOC Ltd, UK) coupled to an infrared gas analyser controller (Eurotherm Ltd, UK) which continuously ventilated air in the chambers and pulsed $\mathrm{CO}_{2}$ accordingly. Natural daylight in the chambers was supplemented using SonT sodium vapour lamps (Phillip Ltd, Holland) during the winter months to maintain a 12 -h photoperiod. Monitors (Telaire Ltd, UK) were used to measure $\mathrm{CO}_{2}$, temperature and humidity at 6-min intervals in each chamber, and the data recorded to dataloggers (Hobo Inc., USA). In the first experiment, the overall mean temperature was $24{ }^{\circ} \mathrm{C}$, and the mean humidity was $85.4 \%$. In the second experiment, the mean temperature was $25.2{ }^{\circ} \mathrm{C}$, and the mean humidity was $86.3 \%$. Ranges in temperature were within that normally experienced in the field for this crop.

At $50 \%$ anthesis, the following physiological parameters were measured: assimilation rate $(A)$, stomatal conductance $\left(g_{\mathrm{s}}\right)$, transpiration rate $(E)$ and the intercellular $\mathrm{CO}_{2}$ concentration $(\mathrm{Ci})$ on the three youngest top expanded leaves of all plants using a LCi-SD Portable photosynthesis system (ADC Ltd, UK) equipped with a $6-\mathrm{cm}^{2}$ chamber, and the lamp was operated at $11 \mathrm{~V}$ DC. In both experiments, the same three youngest leaves used for physiological parameters were used to determine nitrogen and chlorophyll content 1 day after the measurement of physiological parameters. Half of the plants in each chamber in the first experiment and all plants of the six 
chambers (three from each ambient and elevated) were harvested, and two chambers, one from each treatment, were left to mature until harvest. Leaf area was measured for all plants at anthesis using an image analysis system (DIASTM Delta-T Instruments Ltd, UK), and the LAI was calculated by dividing total leaf area by pot surface area. From the harvested plants, three plants from each chamber were sub-sampled, and three sub-samples were used to determine chlorophyll content and three other samples used to determine leaf nitrogen content in the first experiment. In the second experiment, two subsamples were taken from two plants from each nitrogen treatment in each chamber for chlorophyll and nitrogen content determination; other plants were separated into above-ground fractions (stem, branch, leaf and capitula) and dried at $80^{\circ} \mathrm{C}$ for $8 \mathrm{~h}$ in a forced air drying oven (Gallenkamp Ltd, UK), and total above-ground dry weight was recorded. Leaf nitrogen concentration was determined using Kjeldahl analysis according to Rudmann et al. (2001), and chlorophyll content on a fresh weight basis was determined using a spectrophotometer set at 645 and $663 \mathrm{~nm}$ against an $80 \%$ acetone solvent blank (Taiz and Fizeiger 2002). The amount of chlorophyll present in the extract was calculated on the basis of milligrammes of chlorophyll per gramme of leaf tissue according to the following equations:

$\mathrm{mg}$ chlorophyll a $/ \mathrm{g}$ tissue $=[12.7(\mathrm{D} 663)-2.69(\mathrm{D} 645)]$

$$
\times \mathrm{V} / 1,000 \times \mathrm{W}
$$

$\mathrm{mg}$ chlorophyll b/g tissue $=[22.9(D 645)-4.68(D 663)]$

$$
\times V / 1,000 \times W
$$

$\mathrm{mg}$ total chlorophyll $/ \mathrm{g}$ tissue $=[20.2(\mathrm{D} 645)+8.2(\mathrm{D} 663)]$

$$
\times \mathrm{V} / 1,000 \times \mathrm{W}
$$

$\mathrm{mg}$ total chlorophyll $/ \mathrm{g}$ tissue $=\mathrm{D} 652 \times 1,000 / 34.5$

$$
\times \mathrm{V} / 1,000 \times \mathrm{W}
$$

$D$ The optical density reading of the chlorophyll extract at the specific indicated wavelength

$V$ The final volume of the $80 \%$ acetone-chlorophyll extract

$W \quad$ The fresh weight in grammes of the leaf extracted

Statistical analyses of data were performed using Minitab V. 15 using two-way ANOVA in the first experiment and using Minitab V. 15 using nested ANOVA for the second experiment. Least significant difference $\left(\mathrm{LSD}_{0.05}\right)$ was calculated to indicate differences between treatments. Response curves were fitted to data using sequential polynomial fitting to maximise the coefficients of determination, and all curves presented are second-order polynomials with $R^{2}$ values between 0.80 and 0.99 .

\section{Results and discussion}

\subsection{Gas exchange and assimilation rate}

This research reports the results of an investigation of the physiological response of the semi-arid oil-seed crop safflower to elevated $\mathrm{CO}_{2}$. Elevated $\mathrm{CO}_{2}$ significantly $(p<0.001)$ increased the mean assimilation rate $(A)$ by $27 \%$ compared to ambient at anthesis (Table 1). This was interpreted as a result of increased $\mathrm{CO}_{2}$ at a carboxylation site of Rubisco and inhibited photorespiration. Such responses are commonly reported (Ainsworth and Long 2005; Ainsworth and Rogers 2007). In fact, it has been reported that elevated $\mathrm{CO}_{2}$ enhanced assimilation rate in $\mathrm{C}_{3}$ plants by $31 \%$, but the magnitude of the increment varied among different species and environments (Ainsworth and Rogers 2007). In general, some modelling studies have reported that assimilation rates were sustained over the time at short-term exposure to rising $\mathrm{CO}_{2}$, but were down regulated after long-term exposure to $\mathrm{CO}_{2}$ enrichment (Ainsworth et al. 2002). From his review, Ainsworth et al. (2002) revealed that down regulation in photosynthetic capacity (acclimation) after long-term exposure to elevated $\mathrm{CO}_{2}$ was related to the size of the pot in which plants were grown because the volume of the pots impacted on the sink size by restricting root growth. Elevated $\mathrm{CO}_{2}$ significantly $(p<0.001)$ reduced stomatal conductance $\left(g_{\mathrm{s}}\right)$ by an average of $29 \%$ (Table 1), and as a consequence, the transpiration rate $(E)$ was significantly $(p<0.001)$ reduced by $18 \%$ under elevated $\mathrm{CO}_{2}$ (Table 1). These reductions may be attributed to improvements in WUE and enhanced the assimilation rate as reported elsewhere (Hsiao et al. 1999). However, the reduction in transpiration rate that resulted from increased $\mathrm{CO}_{2}$ is altered somewhat by larger leaf area induced by doubled $\mathrm{CO}_{2}$ so that the effect of elevated $\mathrm{CO}_{2}$ on plant growth is offset (Allen 1999).

It has been frequently reported that increases in both atmospheric $\mathrm{CO}_{2}$ concentration and nitrogen supply result in large and sustained increases in light-saturated assimilation rate (Johnson et al. 1995; Radoglou et al. 1992; SanzSáez et al. 2010). For example, $\mathrm{CO}_{2}$ elevated to $700 \mu \mathrm{mol} \mathrm{mol}^{-1}$ resulted in an increase of 30 and $40 \%$ in assimilation rate under high nitrogen and low nitrogen (without nitrogen supplied), respectively, as compared to ambient $\mathrm{CO}_{2}\left(350 \mu \mathrm{mol} \mathrm{mol}^{-1}\right)$ in fully expanded primarily leaves of Phaseolus vulgaris (Radoglou et al. 1992). 
Table 1 Leaf physiological characteristics at anthesis of safflower grown under ambient and elevated $\mathrm{CO}_{2}$

\begin{tabular}{lll}
\hline$n=16$ & $\begin{array}{l}\text { Ambient } \\
\mathrm{CO}_{2} \text { mean } \\
\left(\mathrm{SE}_{0.05}\right)\end{array}$ & $\begin{array}{l}\text { Elevated } \\
\mathrm{CO}_{2} \text { mean } \\
\left(\mathrm{SE}_{0.05}\right)\end{array}$ \\
\hline $\begin{array}{c}\text { Assimilation rate }(A), \\
\mu \mathrm{mol} \mathrm{m} \mathrm{s}^{-1}\end{array}$ & $13.17(1.22)$ & $927(0.98)$ \\
$\begin{array}{c}\text { Stomatal conductance }\left(g_{\mathrm{s}}\right), \\
\mathrm{mmol} \mathrm{m}^{-2} \mathrm{~s}^{-1}\end{array}$ & $0.221(0.042)$ & $0.316(0.019)$ \\
$\begin{array}{c}\text { Transpiration rate }(E), \\
\text { mmol m} \mathrm{s}^{-1}\end{array}$ & $4.79(0.417)$ & $5.83(0.313)$ \\
$\begin{array}{c}\text { Sub-stomatal CO} \\
\mu \mathrm{Cmol} \mathrm{mol} \mathrm{CO}^{-1}\end{array}$ & $504.4(17.78)$ & $451.1(44.44)$ \\
\hline
\end{tabular}

The results obtained in the second experiment presented here confirmed these findings. At anthesis, all levels of nitrogen supplied under elevated $\mathrm{CO}_{2}$ (to $1,000 \mu \mathrm{mol} \mathrm{mol}^{-1}$ ) increased assimilation rate $(A)$ by $18 \%$ as compared to ambient $\mathrm{CO}_{2}\left(400 \mu \mathrm{mol} \mathrm{mol}{ }^{-1}\right)$, and elevated $\mathrm{CO}_{2}$ resulted in an increase of $15 \%$ in assimilation rate for plants grown with the highest nitrogen supply and $26 \%$ for plants grown under the lowest nitrogen supply (Fig. 2). This increase was a result of increased intercellular $\mathrm{CO}_{2}$ concentration $(\mathrm{Ci})$ and compensated for limited nitrogen-grown plants under elevated $\mathrm{CO}_{2}$; as a result, the stomatal conductance $\left(g_{\mathrm{s}}\right)$ and, correspondingly, transpiration rate $(E)$ did not significantly $(p>0.0)$ decline under the effect of elevated $\mathrm{CO}_{2}$. At both ambient and elevated $\mathrm{CO}_{2}$, stomatal conductance and transpiration rate significantly $(p<0.05)$ increased, respectively, by 26 and $24 \%$ at $125 \mathrm{~kg} \mathrm{~N}^{-1}$ as compared to the lowest nitrogen levels (Fig. 2) which was consistent with the finding that stomata have been shown to be sensitive to the intercellular $\mathrm{CO}_{2}$ concentration (Mott 1988). This can be interpreted as the carboxylation capacity of ribulose-1, 5-bisphosphate carboxylase/oxygenase protein (Rubisco) under elevated $\mathrm{CO}_{2}$ at high nitrogen (Ainsworth and Long 2005; Ainsworth and Rogers 2007; Jifon and Wolfe 2002). The results presented here also support those previously reported by Radoglou et al. (1992). The results in this study suggest that the effects of $\mathrm{CO}_{2}$ and nitrogen on assimilation rate are independent of each other. However, Anten et al. (2004) found an interactive effect of nitrogen and $\mathrm{CO}_{2}$ on canopy carbon gain, indicating that photosynthesis rate is dependent on both, and showed that this interaction resulted from an increase in LAI with increasing nitrogen input, which led to the positive effect of receiving a higher quantum yield of light at elevated $\mathrm{CO}_{2}$. In fact, the interactive effect between $\mathrm{CO}_{2}$ and
Fig. 2 Trends in aspects of assimilation (assimilation rate, stomatal conductance, substomatal $\mathrm{CO}_{2}$ and transpiration rate) of safflower grown under ambient and elevated $\mathrm{CO}_{2}$ at varying levels of nitrogen availability showing how assimilation rate is raised with elevated $\mathrm{CO}_{2}$ as a result raising internal leaf $\mathrm{CO}_{2}$ levels. This response is consistently evident across all nitrogen levels, and nitrogen improved the response with each increment. Stomatal conductance and transpiration rate were unaffected by the level of $\mathrm{CO}_{2}$ but responded to nitrogen incrementally
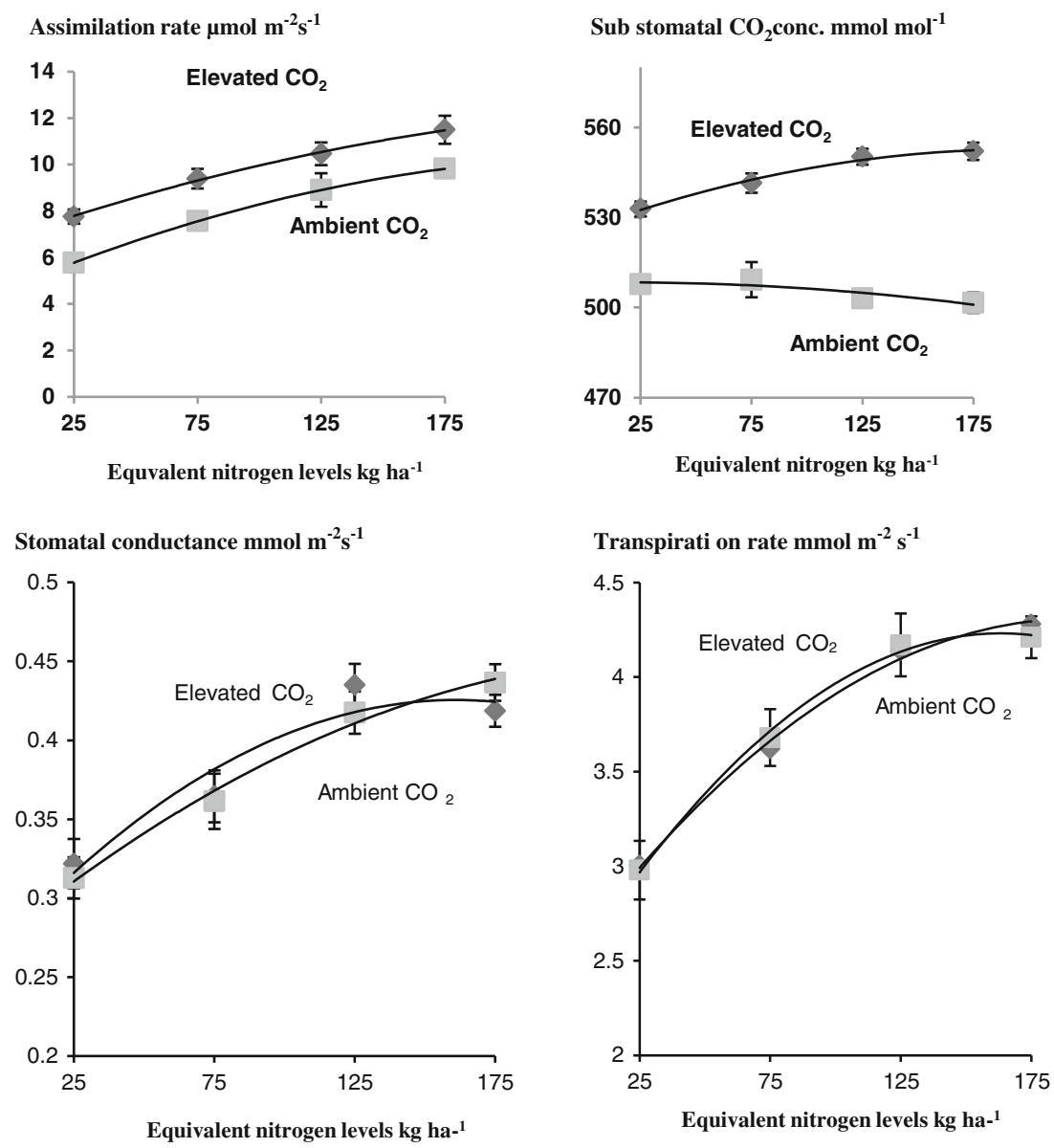
nitrogen on photosynthetic rate and growth could operate through two mechanisms: nitrogen uptake which decreases photosynthetic acclimation to elevated $\mathrm{CO}_{2}$, and this has previously been shown to be more obvious when nitrogen is limited (Stitt and Krapp 1999), or long exposure to elevated $\mathrm{CO}_{2}$ which can lead to photosynthetic acclimation caused by carbohydrate accumulation, which tends to be more pronounced under lower than higher nitrogen availability (Ainsworth and Rogers 2007).

In contrast to these studies, under conditions where nitrogen deficiency decreased leaf area, assimilation and sugar levels and increased allocation of biomass to non-photosynthetic tissue and photosynthetic acclimation to elevated $\mathrm{CO}_{2}$ were more pronounced in high compared to low nitrogen supply (Jifon and Wolfe 2002). Moreover, Rubisco has not been shown to decrease with nitrogen deficiency under elevated $\mathrm{CO}_{2}$ (Farage et al. 1998).

\subsection{Nitrogen and chlorophyll content}

In the first experiment, the youngest fully expanded leaves significantly concentrated less nitrogen at elevated $\mathrm{CO}_{2}$ compared with ambient $\mathrm{CO}_{2}$.

Chlorophyll $\mathrm{a}$ and $\mathrm{b}$, and total chlorophyll were not significantly affected by elevated $\mathrm{CO}_{2}$ treatment (Table 2). This trend is consistent with the observation that plants change their nitrogen allocation to optimize energy cost (Jablonski et al. 2002). Moreover, this was interpreted in turn by the increased ability of plants to use nitrogen more efficiently as a result of the marked increase in photosynthetic rate at doubled $\mathrm{CO}_{2}$ (Cruz et al. 2003). Another explanation is the consequence of a decrease of transpiration rate that resulted from reduced stomatal closure in response to elevated $\mathrm{CO}_{2}$ which possibly limited plant nitrogen uptake from the root environment, but this possible explanation has received little attention in the literature (Kanemoto et al. 2009).

Safflower leaves concentrated less nitrogen which did not lead to big changes in chlorophyll content at elevated $\mathrm{CO}_{2}$ (Fig. 3). Previous work on cotton (Delucia et al. 1985)

Table 2 Leaf nitrogen and chlorophyll contents at anthesis of safflower grown under ambient and elevated $\mathrm{CO}_{2}$

\begin{tabular}{lcc}
\hline$n=3$ & $\begin{array}{l}\text { Ambient } \mathrm{CO}_{2} \\
\text { mean }\left(\mathrm{SE}_{0.05}\right)\end{array}$ & $\begin{array}{l}\text { Elevated } \mathrm{CO}_{2} \\
\text { mean }\left(\mathrm{SE}_{0.05}\right)\end{array}$ \\
\hline $\begin{array}{l}\text { Leaf nitrogen, } \\
\mathrm{g} 100 \mathrm{~g}^{-1} \text { dry wt }\end{array}$ & $2.70(0.162)$ & $3.57(0.189)$ \\
$\begin{array}{c}\text { Chlorophyll a, } \\
\mathrm{mg} \mathrm{g}^{-1} \text { fresh wt }\end{array}$ & $0.52(0.089)$ & $0.48(0.054)$ \\
$\begin{array}{c}\text { Chlorophyll b, } \\
\mathrm{mg} \mathrm{g}^{-1} \text { fresh wt }\end{array}$ & $0.50(0.051)$ & $0.48(0.049)$ \\
$\begin{array}{c}\text { Total chlorophyll, } \\
\mathrm{mg} \mathrm{g}^{-1} \text { fresh wt }\end{array}$ & $1.32(0.067)$ & $1.28(0.093)$ \\
\hline
\end{tabular}

proposed that elevated $\mathrm{CO}_{2}\left(1000 \mu \mathrm{L} \mathrm{L}^{-1}\right)$ reduced leaf chlorophyll content, and the ratio of chlorophyll $\mathrm{a} / \mathrm{b}$ changed with reductions in transpiration rate and nitrogen content. The reduction in leaf chlorophyll content under elevated $\mathrm{CO}_{2}$ was attributed to mild chlorosis in leaf in response to $\mathrm{CO}_{2}$ increase.

In the second experiment reported here, at anthesis, elevated $\mathrm{CO}_{2}$ also significantly $(p<0.05)$ reduced nitrogen concentration in expanded leaves with an $8 \%$ reduction compared to ambient $\mathrm{CO}_{2}$ (Fig. 3), with the greatest reduction under the lowest nitrogen levels. There was no significant $\mathrm{CO}_{2}$ and nitrogen interaction. It can be concluded that the reduction in plant leaf nitrogen concentration under elevated $\mathrm{CO}_{2}$ and at all nitrogen treatments did not lead to photosynthetic acclimation, and photosynthetic acclimation has been strongly related to a decrease in leaf nitrogen concentration under low nitrogen supply (Ainsworth and Long 2005). As mentioned earlier, the mean photosynthetic rate $(A)$ for plants grown under the lowest nitrogen level was significantly $(p<0.05)$ higher than for the plants grown under the lowest nitrogen level at ambient $\mathrm{CO}_{2}$. Therefore, this study lends further support to the hypothesis that elevated $\mathrm{CO}_{2}$ improves the photosynthetic NUE. In agreement with our study, the photosynthetic NUE in sunflower (Helianthus annuus L.) increased by an average of $50 \%$ in sunflower at $\mathrm{CO}_{2}$ enrichment over ambient (Zerihun et al. 2000). Similarly, elevated $\mathrm{CO}_{2}$ significantly $(p<0.05)$ reduced leaf chlorophyll content, and the most reduction was at the lowest nitrogen input (Fig. 3), with a 4, 5 and $8 \%$ reduction in chlorophyll a and $\mathrm{b}$, and total chlorophyll, respectively, under the elevated $\mathrm{CO}_{2}$ as compared to ambient $\mathrm{CO}_{2}$, and a reduction of 24,44 and $31 \%$ in chlorophyll a and $\mathrm{b}$, and total chlorophyll, respectively, at the lowest nitrogen supplied under elevated $\mathrm{CO}_{2}$ as compared with the highest nitrogen supplied. There was a significant $\mathrm{CO}_{2} \times$ nitrogen interaction for total chlorophyll (Fig. 3). One reason for chlorophyll reduction at elevated $\mathrm{CO}_{2}$ may be related to a reduction in nitrogen uptake (Nakano et al. 1997) resulting in a decrease in leaf chlorophyll content which resulted in chlorosis as previously reported (Radoglou et al. 1992). In a 2-year study on spring wheat (Triticum aestivum L. cv. Alcala), in one of the years, leaf chlorophyll content was not significantly $(p>0.05)$ changed by $\mathrm{CO}_{2}$, but it was significantly reduced under nitrogen deficiency. However, in the other year, the acclimation of leaf photosynthesis rate $(A)$ and stomatal conductance $\left(g_{\mathrm{s}}\right)$ in elevated $\mathrm{CO}_{2}$ over the ambient $\mathrm{CO}_{2}$ were associated with lower total leaf chlorophyll content (Del Pozo et al. 2005) indicating that other factors are also interacting with those measured. There was no significant $(p>0.05)$ interaction effect of elevated $\mathrm{CO}_{2}$ and nitrogen reported here on leaf nitrogen concentration and all types of chlorophyll content as all increased with each increase in nitrogen levels at both ambient and elevated $\mathrm{CO}_{2}$. In contrast, Jifon and Wolfe 
Fig. 3 Trends in aspects of leaf composition (nitrogen and chlorophyll content) of safflower grown under ambient and elevated $\mathrm{CO}_{2}$ at varying levels of nitrogen availability showing elevated $\mathrm{CO}_{2}$ has a small but consistent effect of lowering nitrogen and chlorophyll content. Increased nitrogen application incrementally increased both nitrogen and chlorophyll content
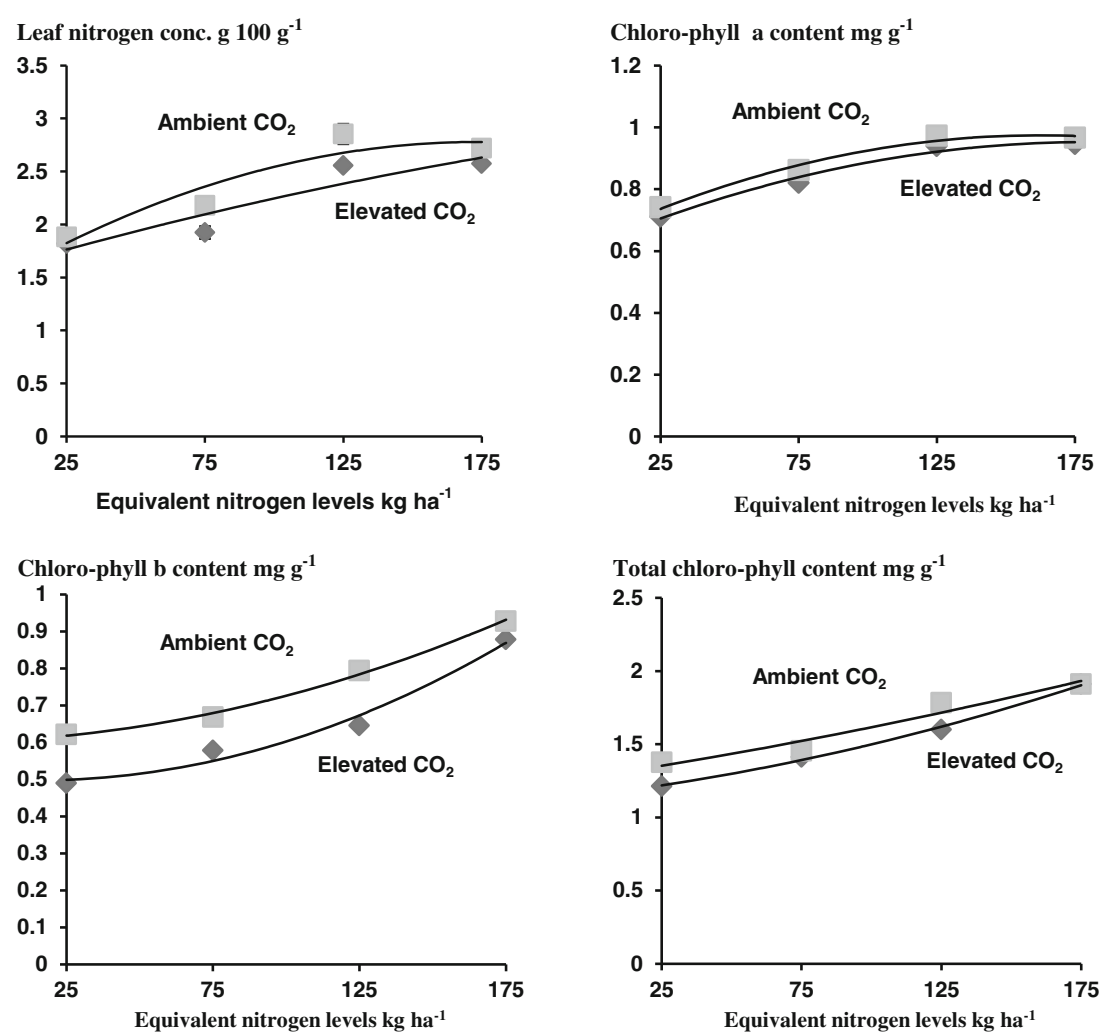

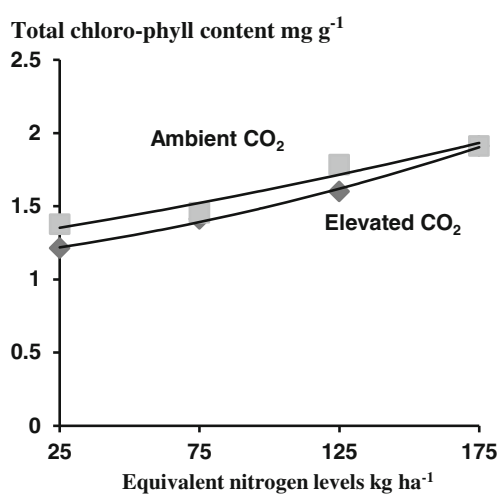

(2002) stated that leaf nitrogen and chlorophyll concentration were not significantly affected by elevated $\mathrm{CO}_{2}$, and the leaf nitrogen concentration was higher under lower nitrogen than high nitrogen, while the chlorophyll content was significantly higher in high-nitrogen than low-nitrogen plants in all $\mathrm{CO}_{2}$ levels.

\subsection{Leaf area index and biomass}

In the first experiment, elevated $\mathrm{CO}_{2}$ significantly increased LAI by $28 \%$ compared to ambient at anthesis (Table 3 ). The total above-ground dry weight subjected to a higher level of $\mathrm{CO}_{2}$ followed the same pattern as that for LAI at both anthesis and harvest. LAI increased due to an increase in assimilation rate and growth as previously reported by Manderscheid et al. (2003) who found that increased LAI did not lead to a noticeable change in canopy light absorption at elevated $\mathrm{CO}_{2}$. However, some authors predict that LAI would increase in upper canopies under doubled $\mathrm{CO}_{2}$ because elevated $\mathrm{CO}_{2}$ reduces the light compensation point for photosynthesis and thus stimulates leaf production
(Campbell et al. 2001). Others showed no significant effect of elevated $\mathrm{CO}_{2}$ on LAI (Sims et al. 1999) or found that elevated $\mathrm{CO}_{2}$ failed to increase the leaf area and decreased specific leaf area (Ainsworth and Long 2005). There was a strong positive response of above-ground biomass to elevated $\mathrm{CO}_{2}$ observed here with increases of $51 \%$ at anthesis and $43 \%$ at harvest compared to ambient. This increase in biomass could be due to a contribution of photosynthetic capacity improvement due to increased LAI and radiation use efficiency. This result agreed with Manderscheid et al. (2003). In contrast, Yuan et al. (2009) stated that higher resource use efficiency occurred per unit of leaf area rather than increasing the leaf area at elevated $\mathrm{CO}_{2}$, and they found that total plant dry weight increased at high levels of $\mathrm{CO}_{2}$ (600 and $800 \mu \mathrm{mol} \mathrm{mol}^{-1}$ ) but was not correlated with LAI. However, in the experiment reported here, the increased assimilation rate and LAI did not result in a significant increase in seed number.

In the second experiment, the greatest LAI increase was $6 \%$ at $125 \mathrm{~kg} \mathrm{~N} \mathrm{ha}^{-1}$ as compared to $25 \mathrm{~kg} \mathrm{~N} \mathrm{ha}^{-1}$, and this parameter peaked at $125 \mathrm{~kg} \mathrm{~N}^{-1}$ at both $\mathrm{CO}_{2}$ levels (Fig. 4). Such a proportional increase in leaf area and LAI with
Table 3 Leaf area index and biomass of safflower grown under ambient and elevated $\mathrm{CO}_{2}$

\begin{tabular}{|c|c|c|}
\hline & $\begin{array}{l}\text { Ambient } \mathrm{CO}_{2} \\
\text { mean }\left(\mathrm{SE}_{0.05}\right)\end{array}$ & $\begin{array}{l}\text { Elevated } \mathrm{CO}_{2} \\
\text { mean }\left(\mathrm{SE}_{0.05}\right)\end{array}$ \\
\hline Leaf area index (LAI) at anthesis & $4.60(0.02)$ & $4.36(0.03)$ \\
\hline Above-ground biomass dry weight at anthesis, $\mathrm{g}_{\text {plant }}{ }^{-1}$ & $5.48(0.522)$ & $3.13(0.444)$ \\
\hline Above-ground biomass dry weight at harvest, $\mathrm{g} \mathrm{plant}^{-1}$ & $10.00(0.522)$ & $4.01(0.720)$ \\
\hline
\end{tabular}


Fig. 4 Mean of LAI at anthesis $\left(\mathrm{LSD} \mathrm{CO} \mathrm{CO}_{2}=0.04, \mathrm{~N}=0.05\right.$ and $\left.\mathrm{CO}_{2} \times \mathrm{N}=0.07\right)$, total aboveground biomass at anthesis (LSD $\mathrm{CO}_{2}=1.42, \mathrm{~N}=2.01$ and $\mathrm{CO}_{2} \times$ $\mathrm{N}=\mathrm{n} . \mathrm{s}$ ) and total above-ground biomass at harvest $(\mathrm{LSD} \mathrm{CO}=$ 0.68, $\mathrm{N}=0.96$ and $\mathrm{CO}_{2} \times \mathrm{N}=\mathrm{n} . \mathrm{s}$ ) at elevated $\mathrm{CO}_{2}$ and different levels of nitrogen fertiliser. Vertical bars are standard error of the mean $(n=4)$ at 0.05 levels
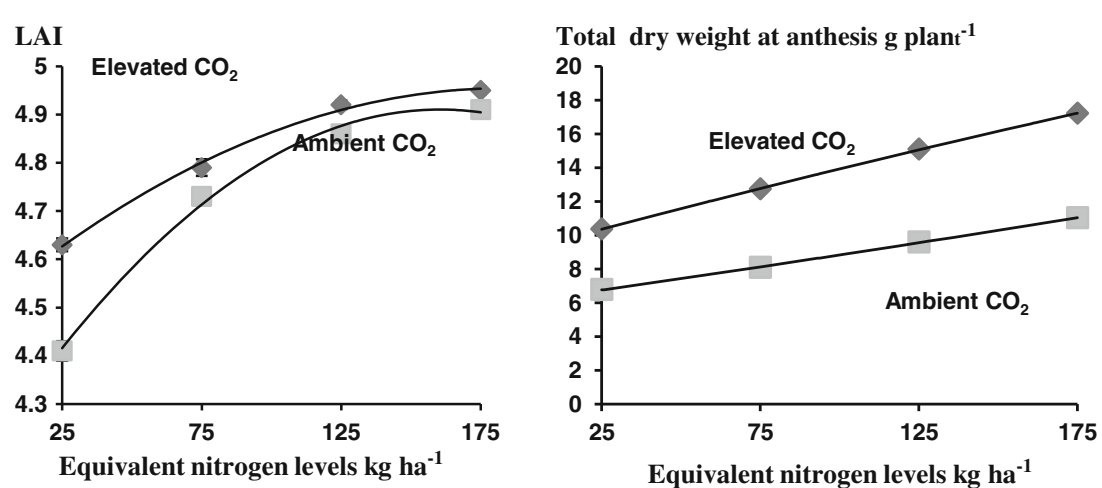

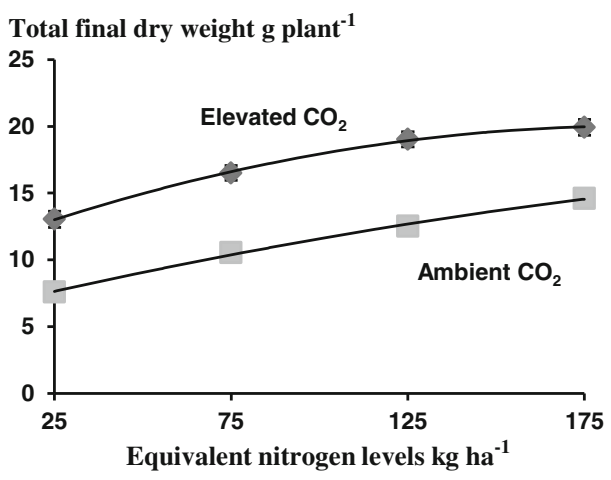

nitrogen input is commonly reported ( $\mathrm{Li}$ et al. 2004). Other studies have also reported that leaf area increased with nitrogen input, but at different $\mathrm{CO}_{2}$ levels, growth was similar (Anten et al. 2004) indicating that optimum LAI does not increase at elevated $\mathrm{CO}_{2}$ when nitrogen is low. Two factors may be responsible for this; one is that plants grown in elevated $\mathrm{CO}_{2}$ have higher quantum yield which makes the leaves in their canopy more nitrogen limited; the other is a possible increase in dark respiration rate under elevated $\mathrm{CO}_{2}$ which leads to a higher light compensation point and lowers LAI (Hirose et al. 1997). Others state that LAI increases at elevated $\mathrm{CO}_{2}$ when nitrogen uptake is high, but not when nitrogen uptake is low (Kim et al. 2001).

In this experiment, increased assimilation rate and leaf area both attributed to the increase in above-ground biomass (Fig. 4). Above-ground dry weight was increased by 35 and $36 \%$ at anthesis and harvest, respectively, under elevated $\mathrm{CO}_{2}$, and the higher values under the higher nitrogen input were 35 and $40 \%$ at anthesis and harvest, at $125 \mathrm{~kg} \mathrm{~N} \mathrm{ha}^{-1}$ as compared with the lowest nitrogen level, respectively. The above-ground dry weight for plants under elevated $\mathrm{CO}_{2}$ and lowest nitrogen rate was $42 \%$ higher than the ambient $\mathrm{CO}_{2}$ and lowest nitrogen rate-grown plants. This suggests that elevated $\mathrm{CO}_{2}$ compensates for the negative effect of nitrogen deficiency. At the same time, nitrogen supply is preventing photosynthesis from $\mathrm{CO}_{2}$ acclimation as reported by Kim et al. (2003). It can be concluded, from the short-term exposure to elevated $\left(700 \mu \mathrm{mol} \mathrm{mol}^{-1}\right)$ and ambient $\mathrm{CO}_{2}$ of alfalfa and three levels of nitrogen fertiliser, that the plants grown under elevated $\mathrm{CO}_{2}$ and zero nitrogen significantly increased photosynthetic activity due to increased nitrogen use efficiency, but there were no significant differences across all $\mathrm{CO}_{2}$ and nitrogen levels, and photosynthetic down regulation had occurred. However, the long-term exposure to elevated $\mathrm{CO}_{2}$ markedly enhanced leaf area and plant biomass over the ambient $\mathrm{CO}_{2}$ when the plant was irrigated with nitrogen and photosynthesis activity was maintained (Sanz-Sáez et al. 2010). This finding clearly supports the hypothesis that growth in limited nitrogen restricted the sink development capacity to utilize the photo assimilate and led to an accumulation of non-structural carbohydrate which increased the $\mathrm{C} / \mathrm{N}$ ratio and exacerbated the acclimation of photosynthesis (Ainsworth et al. 2003; Ainsworth and Rogers 2007). At all nitrogen treatments, elevated $\mathrm{CO}_{2}$ significantly $(p<0.05)$ increased the branch number and corresponding capitula number (data not shown), with the highest values occurring at $125 \mathrm{~kg} \mathrm{~N} \mathrm{ha}^{-1}$. In the present study, there was a significant $(p<0.05)$ interaction effect of $\mathrm{CO}_{2}$ and nitrogen on LAI at anthesis and branch and capitula number at harvest. It can therefore be predicted that the response of branch and capitula number of safflower here is dependent on $\mathrm{CO}_{2}$ concentration, and the data suggest that $125 \mathrm{~kg} \mathrm{~N} \mathrm{ha}^{-1}$ is sufficient for safflower to produce greater LAI, above-ground biomass and the most branches and capitula; this is dependent on LAI and leaf and shoot dry matter accumulation. In support of the results reported here for safflower, cotton showed a significant interaction effect of $\mathrm{CO}_{2}$ and nitrogen on branch and boll number, but no significant interaction effect on plant height and total above biomass (Reddy et al. 2004). The 
explanation for this interactive effect was the increased assimilation rate $(A)$ and growth under elevated $\mathrm{CO}_{2}$; the demand for nitrogen input increases, and a greater sink capacity can be provided and photosynthetic rate sustained.

\section{Conclusions}

The results presented here indicate that $\mathrm{CO}_{2}$ levels, elevated to approximately twice the levels of ambient, and optimal water and nutrient supply increased the assimilation rate in safflower. This increase can be linked to reduction in stomatal conductance and transpiration rate. The above-ground biomass markedly increased and was associated with a noticeable increase in leaf area index and assimilation rate at elevated $\mathrm{CO}_{2}$. It was also shown that the positive $\mathrm{CO}_{2}$ response was maintained at each increase in nitrogen nutrition input. Since the assimilation rate still significantly increased under the lowest nitrogen in response to elevated $\mathrm{CO}_{2}$ compared to ambient $\mathrm{CO}_{2}$, it can also be concluded that the negative impact of nitrogen deficiency on photosynthesis can be ameliorated by elevated $\mathrm{CO}_{2}$. A nitrogen level of $125 \mathrm{~kg} \mathrm{~N} \mathrm{ha}^{-1}$ was sufficient for optimum growth and biomass production in response to elevated $\mathrm{CO}_{2}$. From the interactive effect of $\mathrm{CO}_{2}$ and nitrogen on growth, it can be also concluded that the growth at increased $\mathrm{CO}_{2}$ needed $125 \mathrm{~kg} \mathrm{~N}^{-1}$ to avoid photosynthetic down regulation. Safflower is normally grown in semi-arid soils with low nitrogen content, and the results here show that in the near future, as atmospheric $\mathrm{CO}_{2}$ levels rise, production levels will rise with carbon fertilisation, but extra production will be achieved if nitrogen application levels are raised up to 125 to $175 \mathrm{~kg} \mathrm{~N} \mathrm{ha}^{-1}$.

Acknowledgments The Iraqi Ministry of Higher Education is gratefully acknowledged for a PhD scholarship for Shiren Mohamed.

\section{References}

Ainsworth AE, Davey AP, Bernacchi JC, Dermody CO, Heaton AE, Moore AD, Nargan BP, Naidu LS, Shimyoora H, Guangzhu X, Curtis P, Long PS (2002) A meta-analysis of elevated $\mathrm{CO}_{2}$ on soybean (Glycine max) physiology, growth and yield. Global Change Bio 8:695-709. doi:10.1046/j.1365-2486.2002.00498.x

Ainsworth E, Davey P, Hymus G, Osborne C, Rogers A, Blum H, Nösberger J, Long S (2003) Is stimulation of leaf photosynthesis by elevated carbon dioxide concentration maintained in the long term? A test with Lolium perenne grown for 10 years at two nitrogen fertilization levels under Free Air $\mathrm{CO}_{2}$ Enrichment (FACE). Plant Cell Environ 26:705-714. doi:10.1046/j.1365-3040.2003.01007.x

Ainsworth EA, Long SP (2005) What have we learned from 15 years of free air $\mathrm{CO}_{2}$ enrichment (FACE)? A meta analytic review of the responses of photosynthesis, canopy properties and plant production to rising $\mathrm{CO}_{2}$. New Phytol 165:351-372. doi:10.1111/j.14698137.2004.01224.x
Ainsworth EA, Rogers A (2007) The response of photosynthesis and stomatal conductance to rising $\left[\mathrm{CO}_{2}\right]$ : mechanisms and environmental interactions. Plant Cell Environ 30:258-270. doi:10.1111/ j.1365-3040.2007.01641.x

Allen L Jr (1999) Evapotranspiration responses of plants and crops to carbon dioxide and temperature. In: Kirkham MB (ed) Water use in crop production. Food Products Press Inc, Binghampton, pp 37-70

Anten N, Hirose T, Onoda Y, Kinugasa T, Kim H, Okada M, Kobayashi $\mathrm{K}$ (2004) Elevated $\mathrm{CO}_{2}$ and nitrogen availability have interactive effects on canopy carbon gain in rice. New Phytol 161:459-471. doi:10.1046/j.1469-8137.2003.00943.x

Campbell CS, Heilman JL, McInnes KJ, Wilson LT, Medley JC, Wu G, Cobos DR (2001) Seasonal variation in radiation use efficiency of irrigated rice. Agr For Meteoro 110:45-54. doi:10.1016/S01681923(01)00277-5

Cruz C, Lips H, Martins-Loução MA (2003) Nitrogen use efficiency by a slow-growing species as affected by $\mathrm{CO}_{2}$ levels, root temperature, N source and availability. J Plant Phys 160:1421-1428. doi:10.1078/0176-1617-00998

Dajue LI, Mundle HH (eds) (1996) Safflower. Carthamus tinctorius, International Plant Genetic Resources Institute, Rome

Del Pozo A, Pérez P, Morcuende R, Alonso A, Martínez-Carrasco R (2005) Acclimatory responses of stomatal conductance and photosynthesis to elevated $\mathrm{CO}_{2}$ and temperature in wheat crops grown at varying levels of $\mathrm{N}$ supply in a Mediterranean environment. Plant Sci 169:908-916. doi:10.1016/j.plantsci.2005.06.009

Del Pozo A, Pérez P, Gutiérrez D, Alonso A, Morcuende R, MartinezCarrasco R (2007) Gas exchange acclimation to elevated $\mathrm{CO}_{2}$ in upper-sunlit and lower-shaded canopy leaves in relation to nitrogen acquisition and partitioning in wheat grown in field chambers. Environ Exp Bot 59:371-380. doi:10.1016/j.envexpbot.2006.04.009

Delucia EH, Sasek TW, Strain BR (1985) Photosynthetic inhibition after long-term exposure to elevated levels of atmospheric carbon dioxide. Photosynth Res 7:175-184. doi:10.1007/BF00037008

Drake BG, Gonzàlez-Meler MA, Long SP (1997) More efficient plants: a consequence of rising atmospheric $\mathrm{CO}_{2}$ ? Annu Rev Plant Bio 48:609-639. doi:10.1146/annurev.arplant.48.1.609

Evans R, Belnap J (1999) Long-term consequences of disturbance on nitrogen dynamics in an arid ecosystem. Ecology 80:150-160. doi:10.1890/0012-9658(1999)080[0150:LTCODO]2.0.CO;2

Farage PK, McKee IF, Long SP (1998) Does a low nitrogen supply necessarily lead to acclimation of photosynthesis to elevated $\mathrm{CO}_{2}$ ? Plant Phys 118:573-580. doi:10.1104/pp.118.2.573

Gastal F, Lemaire G (2002) N uptake and distribution in crops: an agronomical and ecophysiological perspective. J Exp Bot 53:789 799. doi: $10.1093 /$ jexbot $/ 53.370 .789$

Hershey DR (1995) Plant biology science project. Wiley, New York

Hirose T, Ackerly D, Traw M, Ramseier D, Bazzaz F (1997) $\mathrm{CO}_{2}$ elevation, canopy photosynthesis, and optimal leaf area index. Ecology 78:2339-2350. doi:10.1890/0012-9658(1997)078[2339: CECPAL]2.0.CO;2

Hsiao TC, Jackson RB, Yiqi L, Harold AM (1999) Interactive effects of water stress and elevated $\mathrm{CO} 2$ on growth, photosynthesis, and water use efficiency. In: Luo Y, Mooney H (eds) Carbon dioxide and environmental stress. Academic, San Diego, pp 3-31

Jablonski LM, Wang X, Curtis PS (2002) Plant reproduction under elevated $\mathrm{CO}_{2}$ conditions: a meta-analysis of reports on 79 crop and wild species. New Phytol 156:9-26. doi:10.1046/j.14698137.2002.00494.x

Jifon JL, Wolfe DW (2002) Photosynthetic acclimation to elevated $\mathrm{CO}_{2}$ in Phaseolus vulgaris $\mathrm{L}$. is altered by growth response to nitrogen supply. Global Change Bio 8:1018-1027. doi:10.1046/ j.1365-2486.2002.00531

Johnson DW, Ball T, Walker RF (1995) Effects of elevated $\mathrm{CO}_{2}$ and nitrogen on nutrient uptake in ponderosa pine seedlings. Plant Soil 168:535-545. doi:10.1007/BF00029366 
Johnston AM, Tanaka DL, Miller PR, Brandt SA, Nielsen DC, Lafond GP, Riveland NR (2002) Oilseed crops for semiarid cropping systems in the northern Great Plains. Agron J 94:231-240. doi:10.2134/agronj2002.2310

Kanemoto K, Yamashita Y, Ozawa T, Imanishi N, Nguyen NT, Suwa R, Mohapatra PK, Kanai S, Moghaieb RE, Ito J (2009) Photosynthetic acclimation to elevated $\mathrm{CO}_{2}$ is dependent on $\mathrm{N}$ partitioning and transpiration in soybean. Plant Sci 177:398-403

Kim YH, Liffering M, Miura S, Kobayashi K, Okada M (2001) Growth and nitrogen uptake of $\mathrm{CO}_{2}$ enrichment rice under field condition. New Phytol 150:223-229. doi:10.1046/j.1469-8137.2001.00111.x

Kim YH, Lieffering M, Kobayashi K, Okada M, Mitchell WM, Gumpertz M (2003) Effect of free air $\mathrm{CO}_{2}$ enrichment and nitrogen supply on the yield of temperate paddy rice crops. Field Crop Res 83:261-270. doi:10.1016/S0378-4290(03)00076-5

Larigauderie A, Hilbert DW, Oechel WC (1988) Effect of $\mathrm{CO}_{2}$ enrichment and nitrogen availability on resource acquisition and resource allocation in a grass, Bromus mollis. Oecologia 77:544549. doi:10.1007/BF00377272

Li F, Kang S, Zhang J (2004) Interactive effects of elevated $\mathrm{CO}_{2}$, nitrogen and drought on leaf area, stomatal conductance, and evapotranspiration of wheat. Agr Water Manag 67:221-233. doi:10.1016/j.agwat.2004.01.005

Manderscheid R, Burkart S, Bramm A, Weigel HJ (2003) Effect of $\mathrm{CO}_{2}$ enrichment on growth and daily radiation use efficiency of wheat in relation to temperature and growth stage. Eur J Agron 19:411-425. doi:10.1016/S1161-0301(02)00133-8

Mott KA (1988) Do stomata respond to $\mathrm{CO}_{2}$ concentrations other than intercellular? Plant Phys 86:200-203. doi:10.1104/pp.86.1.200

Nakano H, Makino A, Mae T (1997) The effect of elevated partial pressures of $\mathrm{CO}_{2}$ on the relationship between photosynthetic capacity and N content in rice leaves. Plant Phys 115:191-198. doi:10.1104/pp.115.1.191

Radoglou K, Aphalo P, Jarvis P (1992) Response of photosynthesis, stomatal conductance and water use efficiency to elevated $\mathrm{CO}_{2}$ and nutrient supply in acclimated seedlings of Phaseolus vulgaris L. Ann Bot 70:257-264, 0305-7364/92/090245+ 12 S08 00/0
Reddy AR, Rasineni GK, Raghavendra AS (2010) The impact of global elevated $\mathrm{CO}_{2}$ concentration on photosynthesis and plant productivity. Current Sci 99:46-54

Reddy KR, Koti S, Davidonis GH, Reddy VR (2004) Interactive effects of carbon dioxide and nitrogen nutrition on cotton growth, development, yield, and fiber quality. Agron J 96:1148-1157. doi:10.2134/agronj2004.1148

Rudmann SG, Milham PJ, Conroy JP (2001) Influence of high $\mathrm{CO}_{2}$ partial pressure on nitrogen use efficiency of the $\mathrm{C}_{4}$ grasses Panicum coloratum and Cenchrus ciliaris. Ann Bot 88:571577. doi:10.1006/anbo.2001.1503

Sanz-Sáez Á, Erice G, Aranjuelo I, Nogués S, Irigoyen JJ, Sánchez-Díaz M (2010) Photosynthetic down-regulation under elevated $\mathrm{CO}_{2}$ exposure can be prevented by nitrogen supply in nodulated alfalfa. J Plant Phys 167:1558-1565. doi:10.1016/ j.jplph.2010.06.015

Shaw MR, Huxman TE, Lund CP (2005) Modern and future semi-arid and arid ecosystems. In: Ehleringer JR et al (eds) A history of atmospheric $\mathrm{CO}_{2}$ and its effects on plants, animals, and ecosystems. Springer Science and Business Media, Inc, New York

Sims DA, Cheng W, Luo Y, Seemann JR (1999) Photosynthetic acclimation to elevated $\mathrm{CO}_{2}$ in a sunflower canopy. J Exp Bot 50:645653. doi:10.1093/jxb/50.334.645

Stitt M, Krapp A (1999) The interaction between elevated carbon dioxide and nitrogen nutrition: the physiological and molecular background. Plant Cell Environ 22:583-621. doi:10.1046/j.13653040.1999.00386.x

Taiz L, Fizeiger E (eds) (2002) Plant physiology (3rd edition). Sinaur Associates Inc., Sunderland, MA, USA

Yuan JS, Himanen SJ, Holopainen JK, Chen F, Stewart CN Jr (2009) Smelling global climate change: mitigation of function for plant volatile organic compounds. Trends Ecol Evol 24:323-331. doi:10.1016/j.tree.2009.01.012

Zerihun A, Gutschick VP, Bassirirad H (2000) Compensatory roles of nitrogen uptake and photosynthetic N-use efficiency in determining plant growth response to elevated $\mathrm{CO}_{2}$ : evaluation using a functional balance model. Annals Bot 86:723-730. doi:10.1006/ anbo. 2000.1234 